\title{
A DOUBLE BLIND, RANDOMIZED, PARALLEL GROUP, PROSPECTIVE, CLINICAL STUDY FOR EVALUATION OF EFFICACY AND SAFETY OF LOW DOSE DOXEPIN IN COMPARISION WITH ZOPICLONE IN ADULT AND ELDERLY PATIENTS WITH PRIMARY INSOMNIA
}

Pali Rastogi1, Deepti Rastogi ${ }^{2}$

${ }^{1}$ Assistant Professor, Department of Psychiatry, MYH Hospital, Indore, Madhya Pradesh.
${ }^{2}$ Demonstrator, Department of Pharmacology, MGM Medical College, Indore, Madhya Pradesh.

ABSTRACT: BACKGROUND: Insomnia is underappreciated public health issue. In recent years, insomnia treatment has advanced beyond the routine use of benzodiazepines.

AIMS: To compare the efficacy and safety of low dose Doxepin with Zopiclone in patients with primary insomnia.

SETTINGS AND DESIGN: A double blind, randomized parallel group, prospective study of low dose Doxepin $(\mathrm{n}=20)$ and Zopiclone $(n=15)$ in patients with primary insomnia.

METHODS \& MATERIAL: Patients fulfilling the selection criteria were enrolled. Enrolled patients were randomized to 2 groups- of low dose Doxepin(3mg) and Zopiclone (3.75mg). Patients were provided with sleep diaries to record sleep parameters, change in alertness and mood, sleepiness scale score and other adverse events were recorded.

STATISTICAL ANALYSIS: Student ' $\mathrm{t}$ ' test.

RESULTS: Both the groups show significant reduction the time of wakening after sleep onset, with improvement in both total sleep time \& sleep efficiency. Both the drugs were well tolerated and percentage change in mood and alertness was comparable.

CONCLUSION: Low dose Doxepin was found to be as effective and safe as Zopiclone in patients of primary insomnia.

KEYWORDS: Low dose Doxepin, Zopiclone, Primary Insomnia.

HOW TO CITE THIS ARTICLE: Pali Rastogi, Deepti Rastogi. “A Double Blind, Randomized, Parallel Group, Prospective, Clinical Study for Evaluation of Efficacy and Safety of Low Dose Doxepin in Comparision with Zopiclone in Adult and Elderly Patients with Primary Insomnia". Journal of Evolution of Medical and Dental Sciences 2015; Vol. 4, Issue 91, November 12; Page: 15603-15608, DOI: $10.14260 /$ jemds/2015/2241.

INTRODUCTION: Insomnia can cause significant emotional distress, fatigue, sleepiness, and impairment of daytime functioning. Impaired social and occupational functioning adversely affects quality of life: people with insomnia have higher rates of mental health problems, drug and alcohol abuse, cardiac morbidity, painful musculoskeletal conditions, and health care utilization. ${ }^{1}$

The international classification divides insomnia into two broad categories of primary or secondary, although many experts now prefer the term "Co Morbid" rather than secondary. ${ }^{2}$

Psychophysiologic insomnia is the most common type of primary insomnia. These patients have insomnia lasting at least 1 month and conditioned sleep difficulty with or without heightened arousal in bed as indicated by one or more of the following. ${ }^{3-5}$ Excessive focus on sleep, heightened anxiety about sleep; difficulty falling asleep in bed at desired time, but not during monotonous activities when not intending to sleep; more able to fall asleep when away from home; mental

Financial or Other, Competing Interest: None.

Submission 01-11-2015, Peer Review 02-11-2015,

Acceptance 04-11-2015, Published 10-11-2015.

Corresponding Author:

Dr. Pali Rastogi,

H. No. 68, Mangal Murti Krishnaji Nagar,

Scheme No.77, (Behind Mayur Hospital),

Bengali Square, Indore-452016, Madhya Pradesh,

Sponsors-Intas pharmaceuticals Ltd,

as the part of Multicentric Clinical Study in India.

E-mail: dr.palirastogi73@gmail.com

DOI:10.14260/jemds/2015/2241. arousal in bed (Intrusive thoughts, perceived inability to cease sleep-preventing mental activity); heightened somatic tension in bed (Perceived inability to relax). Co-morbid insomnia can be associated with medical conditions (e.g. chronic pain, thyroid dysfunction, esophageal reflux), psychiatric disorders (Anxiety, depression, bipolar disorder), neurologic disorders (Parkinson's disease, Alzheimer's disease), primary sleep disorders (Sleep apnea, restless legs syndrome), and drugs.

The management of insomnia requires detailed sleep, medical, and psychiatric histories, including medications, drug and alcohol use, and occupational factors (e.g., shift work), as well as a survey of the sleep environment and sleep-related attitudes and beliefs. Non drug treatments such as cognitive behavioral therapy (CBT) are effective for both primary and co-morbid insomnia. Drug treatments for insomnia are broadly classified into benzodiazepines, benzodiazepines like hypnotics, and miscellaneous sleep promoting agents.

In recent years, insomnia treatment has advanced beyond the routine use of benzodiazepines and benzodiazepine like drugs; newer drug options are less likely to cause tolerance, dependence, and withdrawal. Doxepin used as a hypnotic agent shares many advantages over other available therapies. Use of very low-dose doxepin seems to confer substantial benefit to both objective and subjective measures of sleep maintenance and sleep onset insomnia.

Doxepin was launched in 1969 and has been used for the treatment of depression and associated insomnia and investigated in primary insomnia ${ }^{6}$ at doses of 25$150 \mathrm{mg} /$ day. ${ }^{7-9}$ 
However, more recent studies have examined the use of Doxepin for insomnia, and interest has focused on very low doses ranging from 1 to $6 \mathrm{mg}$ daily, as it seems to be a highly selective Histamine $\mathrm{H}_{1}$ receptor antagonist with few related adverse events when used at very low doses.10-17 Further it has already been approved for insomnia treatment in USA. Doxepin have several distinctive advantages over other available hypnotic agents for several reasons. First, it is a non-controlled substance that enjoys virtually no risk of addiction or dependence.

This allows easier prescribing with fewer prescribing restrictions, as well as being potentially effective in high-risk patient populations (e.g., history of alcohol or drug abuse) and those who require a pharmacologic agent on a more chronic basis. Second, it is has good-quality, placebocontrolled data for use in the elderly, and current data support its safe use even at the highest tested dose of $6 \mathrm{mg}$. Side effects even at the 6-mg dose seemed favorable compared with placebo.

Zopiclone is a hypnotic agent, and a member of the cyclopyrrolone group of compounds. It rapidly initiates and sustains sleep without reduction of total rapid eye movement (REM) sleep and with preservation of slow wave sleep. Its mechanism of action is by binding to the benzodiazepine site and acting as full agonist which in turn positively modulates benzodiazepine sensitive $\mathrm{GABA}_{A}$ receptors and enhances GABA binding at the $\mathrm{GABA}_{A}$ receptors to produce its pharmacological properties. $18,19,20$

This study was undertaken to compare the therapeutic efficacy and safety of low dose Doxepin with that of Zopiclone in the treatment of Indian patients with primary insomnia to test the assumption that Doxepin would be equally effective, safe and well tolerated in comparison to Zopiclone.

MATERIAL \& METHOD: This study was a double blind, randomized, parallel group, prospective, active controlled for evaluation of the efficacy and safety of low dose Doxepin in comparison with Zopiclone in the treatment of primary insomnia in adult and elderly patients.

INCLUSION CRITERIA: Patients of either sex* 18 to 75 years of age, with primary insomnia as defined by the Diagnostic and Statistical Manual of Mental Disordrs, 4th Edition( DSM IV )for at least 1 month, mean subjective 1) Latency of sleep onset (LSO) $\geq 20$ minutes; 2 ) Wake time after sleep onset (WASO) $\geq$ 60 minutes; 3) Total sleep time (TST) $\leq 390$ minutes, based on sleep diary recorded during placebo run-in period and willing to provide written informed consent, were enrolled in the study.

* In case of female with child bearing potential: surgically sterile or using a medically accepted means of contraception with negative urine pregnancy test

\section{Exclusion Criteria:}

\section{Patients meeting any of the following criterions were} excluded:

- History of sleep apnea syndrome, cognitive disorders, depression, schizophrenia, panic disorder, dementia, suicidal tendency, fibromyalgia, seizures (Excluding childhood febrile seizures).

- Chronic pain, glaucoma, frequent nightly urination.
- Significant hepatic, renal, endocrine, cardiovascular, gastrointestinal, pulmonary, hematological, metabolic disorders.

- History of known hypersensitivity to the study drug or any components in their formulation, ongoing therapy with any medication that known to affect sleep pattern.

- Pregnancy or lactation.

- Changes in sleep schedule as a part of his professional duty.

- Participated in another investigational trial within 30 days prior to screening visit were excluded from the trial.

METHOD OF STUDY: Patients fulfilling the selection criteria were enrolled. Enrolled patients were randomized to receive either Doxepin 3mg or Zopiclone 3.75mg. Randomization was done in a double blind fashion.

Study drug was administered as one tablet once daily at night, 30 minutes before going to bed. Patients were instructed not to take study medication within 3 hours of meal. Patients were also provided with sleep diaries.

Sleep diary ${ }^{21}$ has been used to quantify subjectively reported sleep and wake behaviours at the time of screening, baseline and follow up visit to record sleep parameters. It is generally divided into two daily questionnaires completed at bed time and wake time.

The bed time component comprises of timing of meals, medication use and the timing and duration of exercise and nap periods. The wake time questionnaire records bed time, lights out time, sleep latency, final wake time, methods of final awakening, frequency of nightly awakenings, wake after sleep onset time, reasons for nightly awakenings, sleep quality, mood on final awakening and alertness on final wakening.

Thus it permits the calculation of standard research parameters like latency to sleep onset (LSO), total time in bed (TIB), wake time after sleep onset (WASO) and total sleep time (TST).i.e. timings (of going to bed, lights out, final awakening and out of bed), number \& duration of daytime naps and nocturnal awakening as well as duration of falling asleep \& awakening in bed.

All patients had first follow up on day 8 and final second follow up on day 15. After first follow up escalation of study drug dose can be made up to two tablets depending on the response in both the groups.

Patients were not allowed to take any other medications affecting sleep or wake functions or interfering with efficacy and safety evaluation.

\section{STUDY EVALUATIONS:}

Efficacy Parameters: Primary parameter was change in the WASO (Wake time after sleep onset) at the endpoint compared to baseline.

Secondary parameters were change in latency to sleep onset (LSO), total sleep time (TST) and sleep efficiency (SE) at the endpoint compared to baseline.

Safety and Tolerability: Medication tolerability and safety in the two treatment groups were evaluated and compared on the basis of change in alertness and mood on final wakening (Recorded as Visual analog scales), Epworth sleepiness 
scale $^{22}$ score to measure day time sleepiness, other adverse events observed during the study, any clinically significant change in the value of laboratory parameters, vital signs and physical examination during the study compared to baseline.

STATISTICAL ANALYSIS - Student ' $t$ ' test Unblinding of study treatment was done by an independent statistician on completion of study for treatment wise analysis.

RESULTS: Total of thirty five patients with primary insomnia were screened and all of them were enrolled in the study. No patient dropped out during the study.

\begin{tabular}{|c|c|c|}
\hline \multirow[b]{2}{*}{ Parameters } & \multicolumn{2}{|c|}{ Treatment Group } \\
\hline & $\begin{array}{c}\text { Doxepin } \\
(\mathrm{N}=20)\end{array}$ & $\begin{array}{c}\text { Zopiclone } \\
(\mathrm{N}=15)\end{array}$ \\
\hline \multicolumn{3}{|c|}{ Age (Years) } \\
\hline Mean \pm SD & $33.15 \pm 12.82$ & $29.8 \pm 10.05$ \\
\hline \multicolumn{3}{|c|}{ Sex } \\
\hline Male & $13(65 \%)$ & $7(46 \%)$ \\
\hline Female & $7(35 \%)$ & $8(54 \%)$ \\
\hline Body-weight $(\mathrm{kg})($ Mean \pm SD) & $63.65 \pm 6.55$ & $63.4 \pm 8.66$ \\
\hline $\begin{array}{l}\text { Duration of complaint (months) } \\
(\text { Mean } \pm \text { SD) }\end{array}$ & $3.13 \pm 1.41$ & $3.1 \pm 1.83$ \\
\hline BMI (Mean \pm SD) & $24.92 \pm 1.9$ & $24.71 \pm 2.11$ \\
\hline \multicolumn{3}{|c|}{ Table 1: Baseline Patient Characteristics } \\
\hline
\end{tabular}

None of the patient in both the treatment groups had any concomitant illness. None of the patients in both the treatment groups had consumed any concomitant medication during the study. Escalation of study drug dosage was made on Day 8 in $14(70 \%)$ patients; $5(36 \%)$ in Zopiclone and $9(64 \%)$ in Doxepin groups.

\section{Primary Efficacy parameter-WASO Score}

\begin{tabular}{|c|c|c|c|c|c|c|}
\hline \multirow[b]{2}{*}{ Treatment Group } & \multirow{2}{*}{$\begin{array}{c}\text { Baseline WASO } \\
\begin{array}{c}\text { Value } \\
\text { (min) }\end{array}\end{array}$} & \multicolumn{2}{|c|}{$\begin{array}{l}\text { WASO on day } 8 \\
\text { (1 }{ }^{\text {st }} \text { follow-up) }\end{array}$} & \multicolumn{2}{|c|}{$\begin{array}{l}\text { WASO on day } 15 \\
\text { (2nd follow-up) }\end{array}$} & \multirow{2}{*}{$P$ value } \\
\hline & & $\begin{array}{l}\text { Value } \\
\text { (min) }\end{array}$ & $\%$ change & $\begin{array}{l}\text { Value } \\
\text { (min) }\end{array}$ & $\%$ change & \\
\hline $\begin{array}{l}\text { Doxepin } \\
(\mathrm{N}=20)\end{array}$ & $190.25 \pm 43.08$ & $99 \pm 55.15$ & 47.9 & $21.08 \pm 47.27$ & 88.9 & $<0.001$ \\
\hline $\begin{array}{l}\text { Zopiclone } \\
(\mathrm{N}=15)\end{array}$ & $171.56 \pm 38.89$ & $88.56 \pm 53.44$ & 48.38 & $14.22 \pm 35.03$ & 91.71 & $<0.001$ \\
\hline P value & 0.195 & 0.578 & & 0.640 & & \\
\hline
\end{tabular}

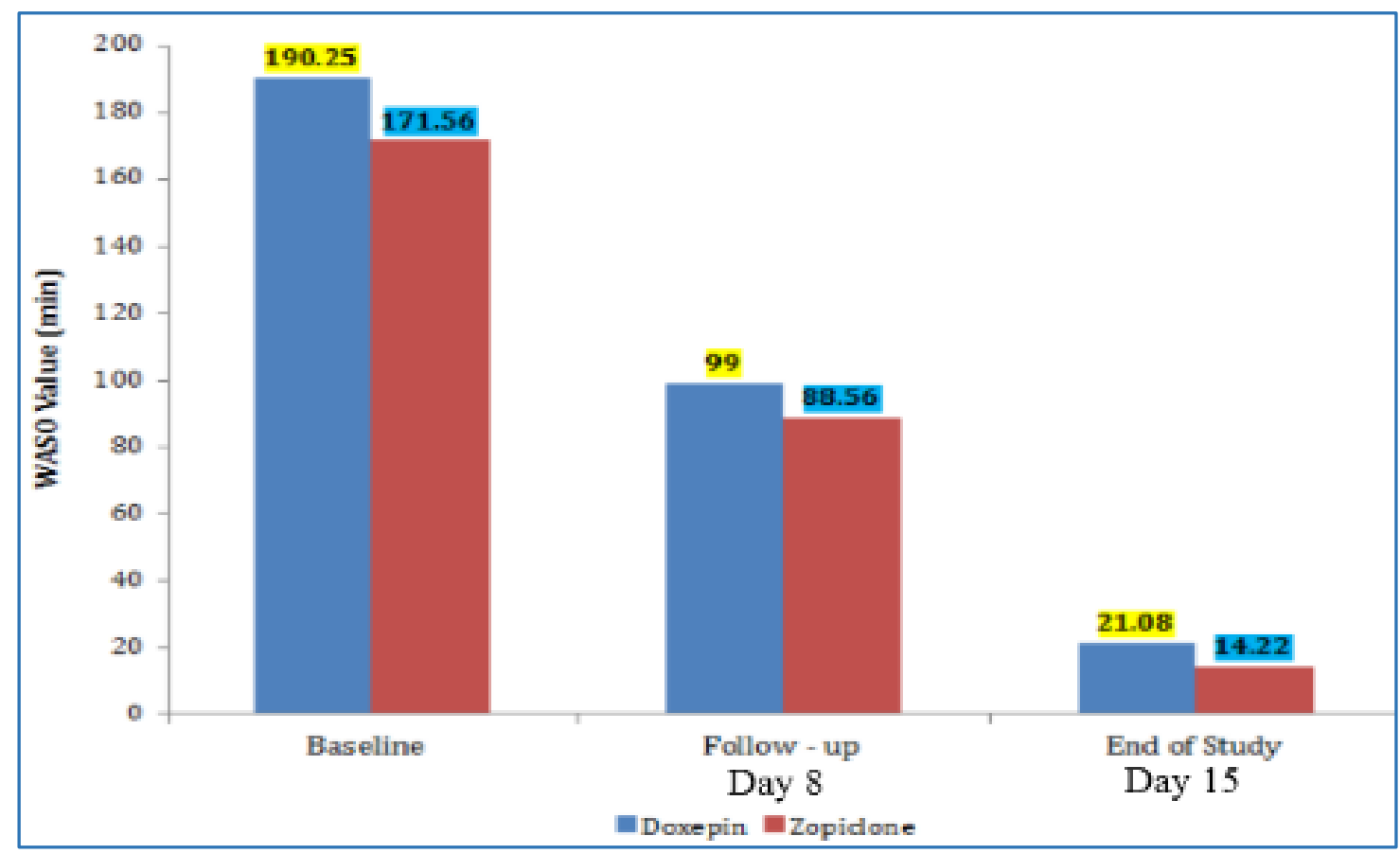

Fig. 1: Change in WASO between two treatment groups

Patients in both the treatment groups i.e. Doxepin and Zopiclone had a significant improvement in sleep maintenance by reduction in the time of wakening after sleep onset. In Doxepin treatment group the percentage reduction was $88.9 \%$ at end of study in comparison to baseline and comparable with Zopiclone treatment group (91.7\%) in WASO values. The difference between the two groups was not significant. 
Secondary Efficacy parameters- Latency to Sleep Onset (LSO)

\begin{tabular}{|c|c|c|c|c|c|c|}
\hline \multirow[b]{2}{*}{ Treatment Group } & \multirow{2}{*}{$\begin{array}{c}\text { Baseline LSO } \\
\begin{array}{c}\text { Value } \\
\text { (min) }\end{array}\end{array}$} & \multicolumn{2}{|c|}{$\begin{array}{c}\text { LSO on day } 8 \\
\text { (1 } 1^{\text {st }} \text { follow-up) }\end{array}$} & \multicolumn{2}{|c|}{$\begin{array}{l}\text { LSO on day } 15 \\
\text { (2nd follow-up) }\end{array}$} & \multirow{2}{*}{$P$ value } \\
\hline & & $\begin{array}{l}\begin{array}{l}\text { Value } \\
\text { (min) }\end{array} \\
\end{array}$ & $\%$ change & $\begin{array}{l}\text { Value } \\
\text { (min) }\end{array}$ & $\%$ change & \\
\hline $\begin{array}{l}\text { Doxepin } \\
(\mathrm{N}=20)\end{array}$ & $136.83 \pm 46.17$ & $80.83 \pm 34.29$ & 40.9 & $16.33 \pm 23.29$ & 88.1 & $<0.001$ \\
\hline $\begin{array}{c}\text { Zopiclone } \\
(\mathrm{N}=15)\end{array}$ & $146.78 \pm 34.25$ & $67.78 \pm 36.05$ & 53.8 & $11.11 \pm 13.94$ & 92.4 & $<0.001$ \\
\hline P value & 0.488 & 0.283 & & 0.447 & & \\
\hline
\end{tabular}

Both treatment groups showed significant reduction in the latency to sleep onset at the end of study treatment as compared to baseline but no significant difference was observed between these groups (Table 3). Thus, Doxepin as well as Zopiclone improved sleep initiation.

Total Sleep Time (TST):

\begin{tabular}{|c|c|c|c|c|c|c|}
\hline \multirow[b]{2}{*}{ Treatment Group } & \multirow{2}{*}{$\begin{array}{c}\text { Baseline TST } \\
\begin{array}{c}\text { Value } \\
\text { (min) }\end{array}\end{array}$} & \multicolumn{2}{|c|}{$\begin{array}{c}\text { TST on day } 8 \\
\text { (1 } 1^{\text {st }} \text { follow-up) }\end{array}$} & \multicolumn{2}{|c|}{$\begin{array}{l}\text { TST on day } 15 \\
\left(2^{\text {nd }} \text { follow-up) }\right.\end{array}$} & \multirow{2}{*}{$P$ value } \\
\hline & & $\begin{array}{l}\text { Value } \\
\text { (min) }\end{array}$ & \% change & $\begin{array}{l}\text { Value } \\
\text { (min) }\end{array}$ & \% change & \\
\hline $\begin{array}{c}\text { Doxepin } \\
(\mathrm{N}=)\end{array}$ & $120.5 \pm 73.71$ & $247.08 \pm 107.3$ & 105.1 & $431.67 \pm 91.23$ & 258.2 & $<0.001$ \\
\hline $\begin{array}{l}\text { Zopiclone } \\
(\mathrm{N}=)\end{array}$ & $126 \pm 83.56$ & $296.78 \pm 103.5$ & 135.5 & $460.11 \pm 57.87$ & 265.2 & $<0.001$ \\
\hline $\mathrm{P}$ value & 0.838 & 0.178 & & 0.298 & & \\
\hline
\end{tabular}

Total sleep time was significantly increased at the follow up visits and at the end of study as compared to baseline. Doxepin group showed 258.2\% increase in TST compared to 265.2\% increase in Zopiclone treatment group.

Sleep Efficiency (SE):

\begin{tabular}{|c|c|c|c|c|c|c|}
\hline \multirow[b]{2}{*}{$\begin{array}{l}\text { Treatment } \\
\text { Group }\end{array}$} & \multirow{2}{*}{$\begin{array}{c}\text { Baseline SE } \\
\text { Value } \\
(\%)\end{array}$} & \multicolumn{2}{|c|}{$\begin{array}{c}\text { SE on day } 8 \\
\left(1^{\text {st }} \text { follow-up) }\right.\end{array}$} & \multicolumn{2}{|c|}{$\begin{array}{c}\text { SE on day } 15 \\
\left(2^{\text {nd }} \text { follow-up) }\right.\end{array}$} & \multirow{2}{*}{$P$ value } \\
\hline & & $\begin{array}{c}\text { Value } \\
(\%)\end{array}$ & $\begin{array}{c}\% \\
\text { change }\end{array}$ & $\begin{array}{c}\text { Value } \\
(\%)\end{array}$ & $\begin{array}{c}\% \\
\text { change }\end{array}$ & \\
\hline $\begin{array}{l}\text { Doxepin } \\
(\mathrm{N}=20)\end{array}$ & $25.97 \pm 14.45$ & $56.89 \pm 20.82$ & 119.1 & $91.36 \pm 16.16$ & 251.8 & $<0.001$ \\
\hline $\begin{array}{l}\text { Zopiclone } \\
(\mathrm{N}=15)\end{array}$ & $27.56 \pm 16.96$ & $64.76 \pm 19.94$ & 135.5 & $94.89 \pm 9.18$ & 244.9 & $<0.001$ \\
\hline P value & 0.775 & 0.268 & & 0.458 & & \\
\hline
\end{tabular}

Low dose Doxepin and zopiclone treatment both significantly increased sleep efficiency in patients with primary insomnia at the end of study as compared to baseline.

\section{SAFETY AND TOLERABILITY:}

\begin{tabular}{|c|c|c|c|c|c|c|}
\hline \multirow{2}{*}{$\begin{array}{c}\text { Treatment } \\
\text { Group }\end{array}$} & Baseline & (1st follow-up) & \multicolumn{2}{c|}{ (2nd follow-up) } & \multirow{2}{*}{ P value } \\
\cline { 2 - 6 } & Value & Value & \% change & Value & $\begin{array}{c}\text { \% } \\
\text { change }\end{array}$ & \\
\hline \multicolumn{7}{|c|}{ Mood of final wakening (VAS score) } \\
\hline Doxepin & $8.8 \pm 6.18$ & $25.73 \pm 12.71$ & 192.4 & $48.27 \pm 12.93$ & 448.5 & $<0.001$ \\
\hline Zopiclone & $7.8 \pm 5.41$ & $25.93 \pm 7.41$ & 232.4 & $51.78 \pm 4.39$ & 563.8 & $<0.001$ \\
\hline \multicolumn{7}{|c|}{ Alertness of final wakening (VAS score) } \\
\hline Doxepin & $9.13 \pm 5.22$ & $24.27 \pm 9.86$ & 165.8 & $46.72 \pm 12.97$ & 411.7 & $<0.001$ \\
\hline Zopiclone & $10.16 \pm 4.83$ & $25.58 \pm 6.46$ & 151.8 & $48.6 \pm 7.92$ & 378.3 & $<0.001$ \\
\hline \multicolumn{7}{|c|}{ Epworth Sleepiness Scale score (ESS) } \\
\hline Doxepin & $13.1 \pm 1.76$ & $7.08 \pm 3.43$ & 45.9 & $1.38 \pm 3.52$ & 89.5 & $<0.001$ \\
\hline Zopiclone & $13.04 \pm 1.27$ & $5.89 \pm 3.17$ & 54.8 & $0.53 \pm 1.42$ & 95.9 & $<0.001$ \\
\hline \multicolumn{7}{|c|}{ Table 6: Change in Mood, Alertness of final wakening and Epworth Sleepiness } \\
\hline
\end{tabular}


Percentage change in mood and alertness of final wakening value was comparable in Doxepin group with respect to Zopiclone treatment group (Table 6). Change in mood and alertness of final awakening reflected less residual effect of both treatment groups. Therefore, during day time, patients were alert and less sedated next day after treatment with both study drugs. Both the study drugs were well tolerated and showed decrease in mean Epworth sleepiness scale (ESS) score at the end of study. ESS data suggested that patients did not suffer from excessive day time sleepiness and resumed their normal daily activity. No adverse event was reported in either groups.

No clinically relevant change from baseline values was found for any monitored parameter [blood chemistry, hematology, urinalysis, and vital signs]. Electrocardiograms (ECGs) were carried out at baseline and end of study for all patients and findings were within normal range.

DISCUSSION: Over recent years, the use of antidepressants for the symptomatic treatment of insomnia has grown substantially but controlled studies are still lacking.

The present study compared the low dose Doxepin with Zopiclone in patients with primary insomnia and have found significant reduction in WASO score as well as in LSO with remarkable improvement in TST and sleep efficiency.

Similar findings were reported by Hajak G et al 2001, who found Doxepin (25-50mg/day) better than placebo. They reported the side effects in two patients (increased liver enzymes, leucopenia and thrombocytopenia) ${ }^{9}$ but in current study no such side effects were reported which may be due to use of low dose Doxepin (3-6mg/day).

As per Weber et al 2015, Doxepin binds with specificity and affinity to the histamine $\mathrm{H}(1)$ receptor compared with other receptors. ${ }^{23}$ Therefore at low doses Doxepin selectively antagonizes H(1) receptors which is believed to promote the initiation and maintenance of sleep as found in our study by decrease in LSO and WASO and increase in TST. Similar findings have been reported in adult patients with insomnia by Richey SM et al, 2011 \& Krystal AD et al, 2011.24-25 and in elderly patients by Scharf M,et al 2008, and Rojas Fernandez CH et al, 2014.26-27

However in meta-analysis of polysomnographic randomized control trials by Winker A et al, 2014 have reported higher effect for benzodiazepine receptor agonist and classical benzodiazepines in comparison to antidepressants (Including low dose Doxepin) but they concluded that additional consideration of side effects profile can lead to alternative treatment decisions. ${ }^{28}$

Both the drugs in the study were safe and tolerable. No adverse effects were reported. In other studies also sideeffects were comparable to placebo. No study with direct comparison between Zopiclone and low dose Doxepin was earlier reported.

LIMITATIONS: The present study is limited because of its short duration. The prospective study with longer follow up, polysomnographic findings and comparison with other treatment alternatives would have been more informative.
CONCLUSION: The present study results suggested that Doxepin reduced WASO and LSO scores (improvement in sleep initiation and maintenance) comparable to Zopiclone in patients with primary insomnia. Doxepin was found to be as good as Zopiclone in terms of safety and tolerability. Thus low dose Doxepin would be an effective and safe option for patients with primary insomnia.

\section{REFERENCES:}

1. Katz DA, McHorney CA. Clinical correlates of insomnia in patients with chronic illness. Arch Intern Med 1998; 158:1099-1107.

2. National Institutes of Health. National Institutes of Health State of the Science Conference statement on Manifestations and Management of Chronic Insomnia in Adults, June 13-15, 2005.Sleep 2005; 28:1049-1057.

3. American Academy of Sleep Medicine. International Classification of Sleep Disorders, 2nd ed. Diagnostic and Coding Manual.

4. Morin CM, Stone J, Trinkle D, Mercer J, Remsberg S. Dysfunctional beliefs and attitudes about sleep among older adults with and without insomnia complaints. Psychol Aging 1993; 8:463-467.

5. Edinger JD, Wohlgemuth WK, Radtke RA, Marsh GR, Quillian RE.Does cognitive-behavioral insomnia therapy alter dysfunctional beliefs about sleep? Sleep 2001; 24:591-599.

6. Roth, T., Zorick, F., Wittig, R., McLeneghan, A., Roehrs, T.The effects of doxepin $\mathrm{HCl}$ on sleep and depression. J Clin Psychiatry 1982, 43(9): 366-8.

7. Hajak, G., Rodenbeck, A., Adler, L. et al. Nocturnal melatoninsecretion and sleep after doxepin administration in chronic primary insomnia. Pharmacopsychiatry 1996, 29(5):187-92.

8. Rodenbeck, A., Cohrs, S., Jordan, W., Huether, G., Ruther, E., Hajak, G. The sleep-improving effects of doxepin are paralleled by a normalized plasma cortisol secretion in primary insomnia. A placebo-controlled, double-blind, randomized, cross-over study followed by an open treatment over 3 weeks. Psychopharmacology 2003, 170(4): 423-8.

9. Hajak, G., Rodenbeck, a., Voderholzer, U. et al. Doxepin in the treatment of primary insomnia: A placebocontrolled, double-blind, polysomnographic study. J Clin Psychiatry 2001, 62(6): 453-63.

10. Stahl SM. Stahl's Essential Psychopharmacology. 3rd ed. New York, NY: Cambridge University Press; 2008

11. Cusack B, Nelson A, Richelson E. Binding of antidepressants to human brain receptors: focus on newer generation compounds. Psychopharmacol (Berl). 1994;114:559-564.

12. Kanba S, Richelson E. Histamine H1 receptors in human brain labelled with 3H-doxepin. Brain Res. 1984;304: 1-7

13. Taylor JE, Richelson E. High-affinity binding of $3 \mathrm{H}-$ doxepin to histamine H1-receptors in rat brain: possible identification of a subclass of histamine H1-receptors. Eur J Pharmacol. 1982;78:279-285. 
14. Kano M, Fukudo S, Tashiro A, et al. Decreased histamine H1 receptor binding in the brain of depressed patients. Eur J Neurosci. 2004;20:803-810.

15. Tashiro M, Sakurada Y, Iwabuchi K, et al. Central effects of fexofenadine and cetirizine: measurement of psychomotor performance, subjective sleepiness and brain histamine H1-receptor occupancy using 11Cdoxepin positron emission tomography. J Clin Pharmacol. 2004;8:890-900.

16. Scavone JM, Greenblatt DJ, Harmatz JS, Engelhardt N, Shader RI. Pharmacokinetics and pharmacodynamics of diphenhydramine $25 \mathrm{mg}$ in young and elderly volunteers. J Clin Pharmacol. 1998;38:603-609.

17. Roth T, Rogowski R, Hull S, et al. Efficacy and safety of doxepin 1,3 and $6 \mathrm{mg}$ in adults with primary insomnia. Sleep. 2007;30:1555-1561.

18. Blanchard JC, Julou L. Suriclone: a new cyclopyrrolone derivative recognizing receptors labeled by benzodiazepines in rat hippocampus and cerebellum. J Neurochem.1983;40(3):601-7.

19. Skerritt JH, Johnston GA. Enhancement of GABA binding by benzodiazepines and related anxiolytics. European Journal of Pharmacology. 1983; 89(3-4):193-8.

20. De Deyn PP, Macdonald RI. Effects of non-sedative anxiolytic drugs on responses to GABA and on diazepam induced enhancement of these responses on mouse neurons in cell culture. British Journal of Pharmacology.1988;95(1):109-20.

21. Michael T. Smith, Stephen T. Wegener. Measures of sleep the insomnia severity index, medical outcomes study(MOS) sleep scale, Pittsburgh sleep diary(PSD), and Pittsburgh sleep quality index(PSQI) Arthritis \& Rheumatism. 2003; 49(5):S184-S196.
22. M. Kaminska, V. Jobin et al. The Epworth Sleepiness scale: self-administration versus administration by the physician and validation of a French version. Can Respir J. 2010;17(2):27-38.

23. Weber J, Siddiqui MA, Wagstaff AJ et al. Low dose doxepin: in the treatment of insomnia. CNS Drugs.2010 ;24(8):713-20.

24. Richey SM, Krystal AD. Pharmacological advances in the treatment of insomnia. Curr Pharm Des. 2011;17(15):1471-5.

25. Krystal AD, Lankford A, Durrence HH et al. Efficacy and safety of doxepin 3 and $6 \mathrm{mg}$ in a 35 day sleep laboratory trial in adults with chronic primary insomnia. Sleep. 2011;34(10):1433-42.

26. Sharf M, Rogowski R, Hull S et al. Efficacy and safety of doxepin $1 \mathrm{mg}$, $3 \mathrm{mg}$ and $6 \mathrm{mg}$ in elderly patients with primary insomnia: a randomized double blind placebo controlled cross over study. J Clin Psychiatry. 2008 ;69(10):1557-64.

27. Rojas Fernandez $\mathrm{CH}$, Chen Y. Use of ultra-dose $(\leq 6 \mathrm{mg})$ doxepin for treatment of insomnia in older people. Can Pharm J (Ott.).2014;147(5):281-9.

28. Winker A, Auer C, Doering BK et al. Drug treatment of primary insomnia: a metaanalysis of polysomnographic randomized controlled trials. CNS Drugs. 2014 ;28(9):799-816. 